tional Institute for Applied Systems Analysis (near Vienna), International Union for Conservation of Nature and Natural Resources (near Geneva), and Worldwatch Institute (Washington); and perhaps as well of the projects in this field by a number of national academies of science, both east and west. It also expects to undertake initiatives in suggesting new activities relevant to the subject, and meanwhile takes this opportunity to solicit suggestions on any aspect of the project.

Stockholm International Peace Research Institute (SIPRI)

Bergshamra

S-17173 Solna

Sweden.

\section{Thoughts on Implementation of the World Campaign for The Biosphere}

Having read with much interest and appreciation the various papers, especially in the Summer 1982 issue of Environmental Conservation, which have described and declared the World Campaign for The Biosphere, I support the Campaign wholeheartedly, but nevertheless feel that its implementation could, and should, be more active than has yet emerged.*

For implementation I do not concern myself with the relative importance, within the Campaign, of education, research, practical action, and institutional change. I agree with Worthington's (1982) statement that education and practical action are mutually supportive, and fundamentally the most important objectives. In addition, research can usually be approved and carried on as needed, while institutional change is likely to follow widespread environmental education and practical action. By implementation I refer rather to the means by which the aforementioned objectives will be accomplished - that is, to planning and management.

Two Authors have addressed this topic. One advocates the preparation of a plan of action formulated by a:

'...small planning group [that] will need to get to work immediately. It would best be composed of a few leading organizations, with perhaps some outside individuals.' (Worthington, 1982).

In contrast the other Author, while suggesting the involvement of various international organizations, states that:

'Although a micro-secretariat of not more than four well-chosen persons with reasonable wherewithal for communications etc. may prove desirable, it is not considered necessary to have any major budget to promote most aspects of the Campaign; indeed the absence of any major financing might well be an advantage inter alia in limiting the promoters to enthusiastic scholars and other dedicated workers lacking financial aspirations and concomitant self-promotional ambitions.' (Polunin, 1982).

It is my firm belief that neither of the above proposals is ideal in view of the Campaign's need to reach as many different people, in as many different places, as soon as possible, and indeed ultimately the whole world.

* Actually, a new world body is currently being organized primarily to foster the Campaign and take it finally off our overburdened shoulders.--Ed.
The main fault that I find with Worthington's scenario is its emphasis on organizational coordination of the Campaign. Inter-group rivalry between environmental and other organizations (both governmental and nongovernmental) is real. Assigning the planning and/or management of the Campaign to one or a few organizations (whether existing or especially created) could be a major tactical error; there are bound to be one or more organizations who would feel resentful of their 'lesser' role in the Campaign. Presumably the major reason for wanting organizations in control of the Campaign is to take advantage of their financial, human, and other resources. But by enlisting, and delegating to, various organizations, a Campaign secretariat could gain the resources of many organizations without chancing the political disadvantages of directly associating the Campaign with specific groups.

It is to the choice of a Campaign secretariat that Polunin addresses himself. The difficulty that I have with the statement quoted above is that it opens the World Campaign for The Biosphere to those two perennial charges against the environmental movement--that it is an elite movement (socially, economically, and scholastically), and that as a result it tends to "preach to the converted'.

In theory it might seem a good idea to choose the Secretariat from knowledgeable, well-known, ostensibly ambitionless scholars. But in practice there are a number of difficulties with this. Firstly it is no more true to say that all scholars are ambitionless than it is to say that all the rest of society are power- and money-hungry social climbers. To be sure, there are scholars who are as Professor Polunin has described, but there are also a great many other people who fit his description of the desired secretariat member. While the financial and personal resources of a scholar would certainly be of use to the Secretariat, it seems foolish to undertake the World Campaign for The Biosphere without also undertaking to find some source of funding for the operation of a small central secretariat. The concept itself is on a grand scale, so why be petty in the organizing of the Campaign?**

There is another objection to a purely 'scholarly' secretariat, and that is the reputation which the scholar has gained, among many people of our world, for 'living in an ivory tower'. If the Campaign gains the reputation of being dependent on another group of scholars 'out to save the world', it would not only produce little that is really new but would also risk alienating a large portion of its potential audience. Without question the experience, contacts, and knowledge, of scholars could be invaluable to the Campaign; but in an advisory, recruited capacity.

To my mind the members of the secretariat, and there should be a small one as Professor Polunin has suggested, should not be scholars. They should be individuals with scholarly and practical experience of environmental conservation and of the environmental movement. They need not be particularly well-known, and certainly should not be controversial, figures. They should be able to converse with scholars, benefactors, businessmen and industry, and the average citizen, with some facility.

\footnotetext{
** It was not so much a matter of pettiness as of belief, from experience. That a dedicated small outfit can commonly do more than a large one consisting of numerous individuals employed in feeding one another and hence lacking concerted thrust.-Ed.
} 
These individuals (and the secretariat in general) would serve an organizing, coordinating, and catalytic, role through writing, speaking, broadcasting, and where feasible travelling in order to undertake on-the-spot organizing and educating. An interesting idea might be to have a member of the secretariat on each continent, who would communicate frequently with the others but meet them less frequently, to attempt to make the Campaign as urgently world-wide as possible on a limited budget.

The members of the Secretariat should be dedicated to the idea of the Campaign, as well as bright, infectiously enthusiastic, and relatively young. One can expect some ambition in such people, which in the right spirit can be all-to-the good. That ambition will be tempered by dedication and experience, and if necessary by supervision by and regular contact with the scholars who conceived the Campaign.

The environmental movement as it is commonly thought of is little more than two decades old; yet some aver that it is slowing down and losing its momentum. Perhaps it is time to innovate a little- the World Campaign for The Biosphere is an innovation. Let its implementation not be a reversion to conservative methods of old. Biswas \& Biswas (1982) believe there is a need for 'specialized generalists'-now might be a good time to find a few potential generalists, and the Campaign a good basis from which to start training them.

\section{REFERENCES}

Biswas, M.R. \& A.K. Biswas (1982). Major requirements for environmental education, Environmental Conservation, 9(2), pp. 125-30.

Polunin, Nicholas (1982). Our global environment and the World Campaign for The Biosphere. Environmental Conservation, 9(2), pp. 115-21, 2 figs.

Worthington, E. Barton (1982). World Campaign for The Biosphere. Environmental Conservation, 9(2), pp. 93-100.

D. SCOTT SLOCOMBE

Integrated Studies

University of Waterloo

Waterloo, N2L $3 G 1$

Ontario, Canada.

\section{Richard St Barbe Baker and The Men of the Trees}

The Men of the Trees is a forestry society which was founded in Africa in 1922, among the tribesmen of $\mathrm{Ke}-$ nya in order to save their land from the deterioration and barrenness which was resulting from the thoughtless destruction of forests. From this grew the idea of a world-wide association that would pledge itself to the cause of trees, whether these be grown for timber, for ornament, for fruit, or for shade. The society's aims are to prevent unnecessary destruction of the world's natural beauty and resources through indiscriminate felling, and to encourage the growing, of trees; for the life and wellbeing of Mankind depend to a considerable extent on maintaining a good sylvan economy.

In 1924 the Society was formed officially in Great Britain, and it was represented at the first world Forestry Congress in Rome in 1926. In 1929 it was established in Palestine and, as a result of a world forestry tour, it became a world-wide Society in 1932 . Today the Society of the Men of the Trees provides a means of universal cooperation in stemming the oncoming tide of destruction, and in reclaiming the waste places of the Earth by large-scale reafforestation. Richard St Barbe Baker, the founder, realized that those who passionately love trees must love their own country, and unstintingly devote themselves to its welfare. Tree-planting is, in fact, a touchstone of true citizenship, for, in planting, Man is ever safeguarding the future.

Our illustrious founder, than whom few can have done more to improve the world, used to say that softwood plantations impoverish the soil and bird-life, and thus harm agriculture. He was certain that clear-felling was not economic except under unusual circumstances. The ideal system is one which will keep the land constantly covered with a forest consisting of uneven-aged trees of various species. What is gained by clear-felling is too often gained at the expense of the future, for it entails the cutting of many small trees which would have eventually grown into profit. We should aim not merely at quantity, but rather at quality. It has been proved by long experience that it pays to work for quality. That means more frequent fellings and a bigger wages' bill, but in the end it will prove to be more economical. Labour-saving does not, in this case, lead towards economy. Growing for quality means the employment of highly-trained foresters, who themselves become responsible for felling and do not leave the work to casual labourers.

\section{The Men of the Trees as a World-wide Network}

Where are the Men of the Trees and what do they do? During the first thirty-four years of their existence, the Men of the Trees saved for posterity many trees and woodlands, besides influencing large-scale reafforestation in Britain and elsewhere. Thanks to a nine-years' struggle to raise the necessary money to rescue California Redwoods (Sequoia sempervirens) from the lumbermen, the finest groves of them were saved. This resulted from the efforts of members of the Men of the Trees, the Society of American Foresters, and others. In the years following, further groups joined in the struggle-patriotic women's groups, etc. Friends of Nature in the USA is affiliated with the Men of the Trees. Thanks to the Men of the Trees in New Zealand, a School of Forestry was established and the Pioneer Park at Raincliff was given to the nation.

In 1954, a special ecological trip across the Sahara was led by St Barbe Baker accompanied by two members of the Men of the Trees, and in 1964 he and members travelled around the Sahara, visiting all the states fringing the desert. The Sahara Reclamation programme was soon established and the northern states led the way with planting. As far away as Manitoba, Canada, ten million trees were planted in a save-the-soil move, again urged by StBarbe, and branches of the Men of the Trees were established in Hong Kong, Jersey, Malta, and eventually in Australia (in 1980). So it is that now there are branches scattered practically throughout the world, and indeed the World Forestry Charter stemmed from the Men of the Trees.

In all the places where it can, the Society assists governments and/or forestry services in the dissemination of educational articles through the press, provides lectures in schools, publishes journal papers and pamphlets, produces films for public exhibition, and, also through lectures and talks, endeavours to mould public opinion so that people everywhere will cooperate with 